Ouachita Baptist University

Scholarly Commons@Ouachita

Articles

Faculty Publications

$12-1991$

\title{
A Title Oscillation: Journal of Comparative Neurology and Psychology, 1904-1910
}

Randall D. Wight

Ouachita Baptist University, wight@obu.edu

Follow this and additional works at: https://scholarlycommons.obu.edu/articles

Part of the History Commons, Journalism Studies Commons, and the Psychology Commons

\section{Recommended Citation}

Wight, R. D. (1991). A title oscillation: Journal of Comparative Neurology and Psychology, 1904-1910. Journal of Comparative Neurology, 314, 34-36. (Centennial celebration issue)

This Article is brought to you for free and open access by the Faculty Publications at Scholarly Commons @ Ouachita. It has been accepted for inclusion in Articles by an authorized administrator of Scholarly Commons @ Ouachita. For more information, please contact mortensona@obu.edu. 


\title{
A Title Oscillation: Journal of Comparative Neurology and Psychology, 1904-1910 1
}

\section{RANDALL D. WIGHT}

Department of Psychology, Ouachita Baptist University, Arkadelphia, Arkansas 71923

\begin{abstract}
From 1904 through 1910, the Journal of Comparative Neurology became the Journal of Comparative Neurology and Psychology. This article attempts a reconstruction of the events behind this title oscillation from archival sources.
\end{abstract}

The month is January; the year, 1903. Robert Mearns Yerkes has just returned from a tour of the German laboratories of Ewald Hering and Wilhelm Wundt. ${ }^{2}$ Yerkes, Harvard's newest instructor in experimental psychology, has been assigned the task of establishing a comparative psychology research program that will outstrip all others.

Yerkes sees his task as launching both a laboratory and his career. To accomplish these tasks in their entirety, he must place his name before the researchers most congenial to his interests. His diary and papers reveal two approaches to increasing his name recognition. First, Yerkes initiates reprint exchanges with other researchers in comparative psychology and in comparative neuroscience. ${ }^{3}$ Second, Yerkes begins to test the waters for a "Journal of Animal Behavior."

In March of 1903, Yerkes writes to zoologist Herbert Spencer Jennings concerning the feasibility of starting such a journal. Jennings responds that the idea is a good one but financing is a serious problem. Yerkes resolves in his diary to talk up the matter and to continue mulling it over. ${ }^{4}$

On the Harvard campus that fall (October 6th), Yerkes chances upon an individual with whom he had earlier exchanged reprints-Charles Judson Herrick, of Denison University in Granville, Ohio. In Massachusetts to address Harvard's Department of Zoology ${ }^{5}$ and spend a couple of months working in the Harvard Library, ${ }^{6}$ Herrick is an internationally-rising star among students of the nervous system, and currently managing editor of the Journal of Comparative Neurology. Yerkes immediately invites Her-rick to a series of social activities. ${ }^{7}$ On November 3rd, following dinner in the home of Walter B. Cannon and writing of that dinner with Cannon and Herrick, Yerkes confides to his diary pleasure regarding his "plan. "8

\footnotetext{
${ }^{1}$ The National Endowment for the Humanities and Ouachita Baptist University provided financial support for this research.

2 Yerkes Diary, 5 January 1903 and 6 January 1903, Yerkes Papers, Manuscript and Archives Division, Yale University Library, New Haven [hereafter, Yerkes Papers).

${ }^{3}$ Letter from C. Judson Herrick to Robert M. Yerkes, 21 March 1903, Yerkes Papers.

4 Yerkes Diary, 25 March 1903, Yerkes Papers; Letter from Herbert S. Jennings to Yerkes, 5 April 1903, Yerkes Papers; Yerkes Diary, 7 April 1903, Yerkes Papers.

${ }^{5}$ Letter from Edward L. Mark to C.J. Herrick, 5 Jone 1903, The Neurology Collections: C.J. Herrick Papers, Department of Special Collections, Kenneth Spencer Research Library, University of Kansas Libraries, Lawrence [hereafter, Herrick Papers]. Mayr ('82) notes that Mark was responsible for guiding the graduate students in Harvard's Department of Zoology.

6 Yerkes Diary, 6 October 1903, Yerkes Papers

7 Yerkes Diary, 16 October 1903, 1 November 1903, 3 November 1903, 8 November 1903, 13 November 1903, Yerkes Papers.

8 Yerkes Diary, 3 November 1903, Yerkes Papers.
} 
Within a week and a half of the Cannon dinner party (November 15th), Herrick returns the social favors and invites Yerkes to lunch. After lunch, Herrick reads Yerkes a manuscript on which he is working and asks Yerkes to offer criticism. After discussing Herrick's manuscript, they take a walk. Yerkes mentions his "scheme" for a journal of animal behavior. The proposal intrigues Herrick. The suggestion emerges that the scope of the Journal of Comparative Neurology expand to include comparative psychology, with Yerkes assuming the editorial responsibilities for the journal's "behavior portion."

Charles' older brother, Clarence Luther Herrick, founded the Journal of Comparative Neurology, considered by many to be the premier journal in American neuroscience since its inception in 1891 (Herrick, '54). Clarence Herrick had managed the journal until 1894 when health problems forced him to move from Ohio to New Mexico and leave the journal in Charles' able hands. ${ }^{10}$ Clarence's name still appeared on the masthead, as it does to this day, and Charles often sought brotherly advice.

In a letter dated November 26, 1903, Clarence heartily endorses the plan to broaden the Journal's horizons and states that this broadening is more in line with his original intent. The elder Herrick feels that the Journal of Compar-ative Neurology has become too narrow and is failing to address the relationship between the nervous system's structure and function. Yerkes and Charles propose that a title change, to the Journal of Comparative Neurology and Comparative Psychology, will best express the new objective. Clarence acknowledges the accuracy of their suggestion but prefers a less radical change to the Journal of Comparative Neurology and Psychology. ${ }^{11}$

Back in Cambridge, Charles and Yerkes have much to do. They spend the next several days in mid-November making personal visits in the Boston area to garner support for the proposed change in an established journal. The duo visits anatomists, physiologists, psychologists, and zoologists of all ilk and find strong support for their venture. ${ }^{12}$ Small pockets of resistance emerge, most notably from psychologists who either (like Cattell and Thorndike) ${ }^{13}$ do not think the enterprise will work or (like Baldwin $)^{14}$ express journal plans of their own. Nevertheless, diplomacy overcomes all resistance. ${ }^{15}$

On December 3rd, 1903 Charles Herrick writes to James Mark Baldwin that, beginning with the next issue, the Journal of Comparative Neurology will definitely become the Journal of Comparative Neurology and Psychology. ${ }^{16}$ In March of 1904, the first issue of the new Journal appears, and with its appearance emerges perhaps America's first truly interdisciplinary journal of neuroscience. Charles Herrick and Robert Yerkes edit, respectively, the structural and functional components of this new journal.

In St. Louis, on September 19th, 1904, while attending the International Congress of Arts and Science, Yerkes receives word from Edmund Sanford of Clark University that Clarence Herrick has died. ${ }^{17}$ This is perhaps the first bad news that the Journal's devotees have heard in a year. Through a concerted letter-writing campaign and personal influence, the Journal's principal editors have doubled their subscription list and finances are on

\footnotetext{
9 Yerkes Diary, 15 November 1903, Yerkes Papers.

${ }^{10}$ For a biography ofC!arencc Luther Herrick, see Windle ('79).

11 Letter from Clarence Luther Herrick to C.J. Herrick, 26 November 1903, Herrick Papers.

12 Yerkes Diary, 16 November 1903, 19 November 1903, 20 November 1903, Yerkes Papers. A particularly interesting incident that Yerkes re-corded (19 November) was a visit to Walter B. Cannon's laboratory where Cannon "treated" Herrick and Yerkes to an X-ray view of the cat digestive system at work.

13 Yerkes Diary, 25 November 1903, Yerkes Papers.

14 Letter from James M. Baldwin to Yerkes, 26 November 1903, Herrick Papers; copy of letter from Yerkes to Baldwin, 27 November 1903, Herrick Papers.

15 Letter from C.J. Herrick to C.L. Herrick, 7 December 1903, Herrick Papers.

${ }^{16}$ Letter from C.J. Herrick to Baldwin, 3 December 1903, Herrick Papers.

17 Yerkes Diary, 19 September 1904, Yerkes Papers.
} 
the upswing. ${ }^{18}$ Reviews among members of the various scientific communities highly praise the first numbers of the Journal of Comparative Neurology and Psychology. ${ }^{19}$

Charles arrives in St. Louis the next day in what Yerkes describes as a "cheerful" mood. ${ }^{20}$ They spend much of the remaining meeting discussing Journal plans and becoming acquainted. A plan that emerges from the St. Louis summit is to promote library acquisition of back issues and to use remaining back issues as advertisements. Although the increase in subscriptions has been a boon to the Journal's coffers, there are still debts to pay. ${ }^{21}$

By early 1905, the editors know that back issues are the mother lode, enriching the Journal. Before the mining can run its course, fire jumps the claim; on March 30th, fire guts Barney Science Hall on the Denison campus where these issues are stored (see Windle, '79). The Journal loses all back issues and most of its zinc and copper illustration plates. Weakened by the loss and by exposure to smoke during the fire, ${ }^{22}$ Herrick works feverishly to restore by hand what can be salvaged for the forthcoming issue (Herrick, '54). Yerkes attempts to milk the tragedy for outside endowment, specifically from Andrew Carnegie. Throughout April, Yerkes successfully marshals written support for such an endowment within the scientific community ${ }^{23}$; Carnegie replies with a succinct "No."24

Although plagued with what Herrick considers poor quality illustrations, the Journal continues to flourish. ${ }^{25}$ Submissions and competition for page space match the increased cost of printing. ${ }^{26}$ During October of 1905, Milton J. Greenman of Philadelphia's Wister Institute of Anatomy and Biology approaches Herrick bout publishing the Institute's neurological material at the Institute's expense. Herrick is elated; Yerkes cautious. ${ }^{27}$

Two years after the fire, through shrewd management, the Journal is debt-free but poor. Greenman makes another overture, suggesting to the surprised Herrick that Wistar assume financial responsibility for the Journal. ${ }^{28}$ Wistar's motive is uncertain, although it already owned the Journal of Morphology and the Anatomical Record. Herrick's motive for considering this proposal is perhaps less uncertain but nevertheless unclear. At various points in his letters he mentions all of the following as reasons: (1) to prohibit the Journal from becoming the mouthpiece of any single university or group of universities; ${ }^{29}(2)$ to permit the Journal to reach its potential; ${ }^{30}(3)$ to provide adequate financial backing ${ }^{31}$; and (4) to give himself rest from editorial duties. $^{32}$

On November 4th, 1907, Herrick informs Yerkes of Wistar's proposal. Herrick tells Yerkes that the invitation's suddenness required unilateral action. He further tells Yerkes he fears that the Journal is becoming perceived as an organ of the University of Chicago and of Harvard, where the two are now employed, but that it must be

\footnotetext{
18 Yerkes Diary, 20 September 1904, Yerkes Papers.

19 Letter from Oliver S. Strong to C.J. Herrick, 22 March 1904, Herrick Papers.

20 Yerkes Diary, 20 September 1904, Yerkes Papers.

21 Yerkes Diary, 20 September 1904, 19 November 1904, Yerkes Papers.

22 Yerkes Diary, 3 April 1905, Yerkes Papers.

${ }^{23}$ Letter from Yerkes to C.J. Herrick, 4 April 1905, Herrick Papers. Yerkes Diary, 4 April 1905, 6 April 1905, 7 April 1905, 9 April 1905, 10 April 1905, 11 April 1905, 12 April 1905, 13 April 1905, 14 April 1905, Yerkes Papers.

24 Yerkes Diary, 15 April 1905, Yerkes Papers. Letter from Yerkes to C.J. Herrick, 17 April 1905, Herrick Papers.

25 Letter from C.J. Herrick to Milton J. Greenman, 25 December 1905, Herrick Papers.

${ }^{26}$ Letters from Jennings to Yerkes, 21 January 1906 and 26 February 1906, Yerkes Papers.

27 Letter from Yerkes to C.J. Herrick, 1 November 1905, Herrick Papers.

28 Letter from C.J. Herrick to Yerkes, 13 November 1907, Herrick Papers.

29 Letter from C.J. Herrick to Yerkes, 4 November 1907, Herrick Papers.

30 Letter from C.J. Herrick to Yerkes, 13 November 1907, Herrick Papers.

31 Letter from C.J. Herrick to Yerkes, 13 November 1907, Herrick Papers.

32 Letter from C.J. Herrick to J.B. Johnson, 5 January 1908, Herrick Papers.
} 
representative of the whole country. Herrick informs Yerkes that Wistar guarantees complete editorial freedom and touts the advantages of more centralized direction. ${ }^{33}$

Again cautious, Yerkes asks of Wistar's commitment to the study of behavior, to which Herrick gives assurances, and of Wistar's potential interest in funding a separate journal of animal behavior, about which Herrick counsels patience. ${ }^{34}$ On January 6th, 1908, Herrick gives the Journal his brother founded to Wistar. Greenman, acting on behalf of Wistar, adds the proviso that should Herrick at any time in the future feel that the Journal could be in better hands then the Institute will return ownership to Herrick or any other individual that he might name. ${ }^{35}$ The title page of the first number of the next volume bears the Wistar name.

Yerkes' enthusiasm for a journal devoted solely to behavior does not wane. In the following years, space within the Journal of Comparative Neurology and Psychology becomes a sought-after premium. Competition for space squeezes the various disciplines, some more than others. Zoologists have the Journal of Experimental Zoology as an outlet; anatomists have the Anatomical Record and the Journal of Morphology; students of animal behavior feel that they have no place to go. ${ }^{36}$ Wistar's requests for Yerkes' patience continue, ${ }^{37}$ but even this most diplomatic of comparative psychologists has his limits. Yerkes informs Herrick of his decision to establish an independent journal in a letter dated 10 August $1910 .{ }^{38}$ In 1911, Robert Yerkes, John B. Watson, and several other prominent psychologists publish the first volume of the Journal of Animal Behavior. That same year, the Journal of Comparative Neurology and Psychology reverts to the Journal of Comparative Neurology.

As neuroscience continues to flourish and as the preeminent journal of neuroscience celebrates its centennial this year, the discipline would do well to consider its struggle to become a multidisciplinary endeavor during the first decade of this century.

33 Letter from C.J. Herrick to Yerkes, 4 November 1907, Herrick Papers.

${ }^{34}$ Letter C.J. Herrick to Yerkes, 5 January 1908, Herrick Papers.

35 Letter from C.J. Herrick to Greenman, 6 January 1908, Herrick Papers; Letter from Greenman to C.J. Herrick, 9 January 1908, Herrick Papaers.

${ }^{36}$ Letter from Yerkes to C.J. Herrick, 23 August 1909, Yerkes Papers.

37 Letter from C.J. Herrick to Yerkes, 30 August 1909, Yerkes Papers; Greenman to Yerkes, 3 September 1909, Herrick Papers.

38 Letter from Yerkes to Herrick, 10 August 1910. 


\section{LITERATURE CITED}

Herrick, C.J. (1954) One hundred volumes of the Journal of Comparative Neurology. J. Comp. Neurol. 100: 717756.

Mayr, E. (1982) The Growth of Biological Thought: Diversity, Evolution, and Inheritance. Cambridge: Harvard University Press.

Windle, W.F. (1979) The Pioneering Role of Clarence Luther Herrick in American Neuroscience. Hicksville, NY: Exposition Press. 